\title{
SCGB2A2 Gene
}

National Cancer Institute

\section{Source}

National Cancer Institute. SCGB2A2 Gene. NCI Thesaurus. Code C113518.

This gene may be involved in mammary development. 